\title{
Leadership among Secondary School Agricultural Science Teachers and Their Job Performance in Akwa Ibom State, Nigeria
}

\author{
Ben, Camilus Bassey \\ Agricultural Education Unit, Department of Vocational and Special Education \\ University of Calabar, Calabar, Nigeria \\ Tel: 234-080-3426-6227_E-mail: bencamilus@yahoo.com
}

Received: September 7, 2011

Accepted: October 2, $2011 \quad$ Published: February 1, 2012

doi:10.5430/wje.v2n1p16

URL: http://dx.doi.org/10.5430/wje.v2n1p16

\begin{abstract}
The main purpose of this study is to investigate leadership among secondary school Agricultural Science teachers and their job performance in Akwa Ibom State. To achieve the aim of this study, three research hypotheses were generated to direct the study. Literature was reviewed based on the variables derived from the postulated hypotheses. Survey research design was adopted for the study. Four hundred (400) respondents were randomly selected for the study. The selection was done through the stratified and simple random sampling techniques. The questionnaire was the main instrument used for data collection. Pearson product moment correlation analysis was employed to test the hypotheses directing the study. The hypotheses were subjected to testing at 0.05 level of significance. The result of the analysis revealed that leadership variables such as creativity, communication competences, and human relation competences, ability to take decisions, health and fitness and intellectual capacity of Agricultural Science teachers significantly relate to their job performance.
\end{abstract}

Keywords: Leadership, Creativity, communication, human relation, job performance

\section{Introduction}

The teaching of agriculture in schools like any other subject cannot be operated in a vacuum, human element must be present. The success or otherwise of any agricultural program in schools depends to a large extent on the personnel available to manage it. It therefore needs efficient, capable, qualified and dedicated individuals in its conduct so that the aims and objectives could be enthusiastically pursued and realized. This could only be achieved through good knowledge of management with adequate managerial parameters, in addition to good leadership of capable and well inform Agricultural Science teachers. It is on this basis that the researcher has deemed it necessary to look into leadership among secondary schools agricultural Science teachers and their job performance in Akwa Ibom State.

Akintunde (2001) defined leadership as the process of influencing others to get the job done effectively over sustained period of time. McNamara (2009) simply defined leadership as establishing direction and influencing others to follow that direction. He further stated that expert assert that, whether you are an executive or an entry-level worker in an organization, it is critical for you to have strong skills in leadership. Whichever style the leader adopts, he must try to gain and maintain the confidence of his colleagues/followers. Without their support, a very little success is likely to be achieved.

Agricultural Science teachers are expected to be leaders since they have to make things happen in the school through the process of influencing others. According to Akintunde (2001), leadership is just one of the important functions performed by the teachers. Other roles of the teachers include: planning, organizing. Staffing, motivating, and attending to the organization. Consequently, being a leader is one of the many requisites of a manager and without leadership skills; managers are not likely to be effective in the discharge of their duties.

In order to be effective, several authors postulated that leaders should posses and demonstrate certain leadership traits. According to Vannier and Gallahue (2008), leaders should display personal interest in their followers; they should be honest, enthusiastic, humane, good speakers, confident and posses knowledge of their vocations. To corroborate the above, Wuest and Bucher (2009) posited that leadership traits such as energy, sense of purpose, enthusiasm, integrity, friendliness and affection, technical mastery, decisiveness, intelligence, technical skills and faith are particularly relevant to leaders in the field of agricultural education. 
Similarly, Horine (2009) submitted that human relations competences, communication competences, creativity, flexibility, vision, mental quickness,

Reliability, courage, enthusiasm, professionalism and technical skills play an important role in continued success in administration. Akintunde (2001) also states that a leader should possess traits like conceptual skills, integrity, ability to instill good human relations, ability to make decisions, health and fitness for the job, willingness to accept responsibility, understanding the job, command of administrative skills and intellectual capacity. The leadership qualities that a good Agricultural Educator should have according to Ikhioya (2001) are many and varied, me of them are sound general education, technical and administrative education, communication, target setting/achievement, positive work influence, behavior consistency, knowledge and skill acquisition, honesty and respect.

\subsection{Statement of the Problem}

Secondary school agriculture in Akwa Ibom State leaves much to be desired going by the performance of students in the state and national examinations. Before the year 2000, Akwa Ibom State had performed poorly in the national examinations. However, the State showed some remarkable improvement in 2002 when it was placed $13^{\text {th }}$ on the performance table by the West African Examinations Council. Since then, the State performances improved tremendously, by it coming $5^{\text {th }}$ in performance ranking in 2004. With that trend of event one expected a better result in 2006 based on improvement in agricultural instructional materials in schools. Disappointingly, the State was rather ranked 21st in performance in 2008, and 31 ${ }^{\text {st }}$ in 2010 (Akwa Ibom State Ministry of Education, 2008)

This downward trend in students' performance in Agricultural Science became a matter of serious concern to the parents and Government of Akwa Ibom State. It engendered thought provoking question. Could the dwindling and poor students' performance in Agricultural Science be related to leadership variables among secondary school Agricultural Science teachers since the Government of Akwa Ibom State has recently made tremendous and appreciable efforts to address poor and inadequate facilities, equipment and funds in schools? It was on the basis of this that the study was conceived.

\subsection{Purpose of the Study}

The main purpose of this study was to appraise the leadership among Akwa Ibom State secondary school agricultural science teachers and their job performance. The specific objectives of the study included:

1) To determine the extent to which creativity in leadership among Agricultural Science teachers relate to their job performance.

2) To find out the extent to which communication in leadership among Agricultural Science teachers relate to their job performance.

3) To ascertain the extent to which human relationship competences in leadership among Agricultural Science teachers relate to their job performance.

\subsection{Research Questions}

The following research questions were posed to guide the study

1) To what extent does creativity in leadership of secondary school Agricultural Science teachers relate to their job performance?

2) How does communication competences in leadership relate to secondary school Agricultural Science teachers' job performance?

3) How does human relation competences of secondary school Agricultural Science teachers relate to their job performance?

\subsection{Research Hypothesis}

The following hypotheses guided the study.

1) There is no significant relationship between Agricultural Science teachers' creativity and their job performance.

2) Communication competences in leadership does not significantly relate to Agricultural Science teachers' job performance.

3) Human relation competences of agricultural science teachers do not significantly relate to their job performance. 


\section{Review of Related Literature}

The review of literature was undertaken under the following headings: concept of leadership, creativity in leadership, communication competences in leadership and human relation competences in leadership

\subsection{Concept of Leadership}

Leadership is imperative for modeling of a group of people into a team, shaping them into a force that serves as a competitive business advantage. Leaders know how to make people function into a collaborative fashion, and how to motivate them to excel in their performance. Leaders also know how to balance the individual members' question with the goal of an outcome that exceeds the sum of individual inputs. Leaders require that their team members forego the question of personal best in concert with the team effort (Adair, 2002). Warren (2000) defined leadership as a complex process by which a person influences others to accomplish a mission, task or objectives and direct the organization in a way that makes it more cohesive and coherent.

Babajide (2000) defined leadership as a process of influencing the activities of an individual or a group's effort toward goal achievement in a given situation. In essence, leadership involves accomplishing goals with or through people. The important thing in this definition is that leadership cannot exist in isolation; there must be the leader and the follower. Leadership involves change in the individual being lead. It influences a process by effectively changing the behavior of others. A leader must therefore be concerned with human relations.

Ayodado (2004) describes a leader as one who succeeds in getting others to follow him and sees leadership as those activities engaged in by an individual or members of a group which contribute significantly to the development and maintenance of role structure and goal direction necessary for effective group activity. By implication, leadership to a large extent involves understanding the environment, identifying the important forces and trend in it, defining purposes, cooperating with others, listening to and understanding others and convincing others through well-thought out and clearly articulated courses of action. Leadership should not be limited to one individual, and the focus of leadership activities should be on increasing the effectiveness of the job performance of the group with whom the leader is working.

Simply put, a leader is seen as someone who sets direction in an effort and influences people to follow that direction. McNamara (2009) in support of this statement affirmed that leading is establishing direction and influencing others to follow that direction. He further stated that there are many variations and different areas of emphasis to this very simple definition as expert have asserted that whether you are an executive or an entry level worker in your organization, it is critical for you to have a strong skill in leadership. Babajide (2000) stated that leadership is accomplishment of a goal through the direction of human assistants. The person who successfully marshals human collaborator to achieve particular ends is a leader. A great leader according to him is one who can do so day after day, year after year in a wide variety of circumstances.

According to Akintunde (2001) people perceived the concept of leadership in different forms. They view it from different angles. To some, it means Charisma while others believe it to means power or a position of authority. The essence of leadership according to him is followership. This implies that it is the willingness of the people to follow that makes a person a leader. Leadership requires the ability of a manager to influence followers to work with confidence and zeal. Richard (2004) sees leadership as the process of influencing the behaviour and attitudes of others to achieve intended outcomes. Like authority, it is a subset of the broad construct of power. He stated further that, there are many definitions of leadership. However, one of the few common denominators among the host of definition is the assumption that leadership involves an intentional influence process of by a leader. Apart from this, leadership is success oriented. If a leader attempts an action and does not get support of followers, leadership has not really taken place. To lead therefore is to guide, conduct, direct and preside. It is the duty of the leader to help a group achieve objective with the maximum application of its capacities. A leader does not stand behind a group to push, he places himself before the group as he facilitate progress and inspires the group to accomplish organizational goals. Sequel to this, leadership can be considered as the process of influencing others to get the job done effectively over a sustained period of time. Bennis (2005) identifies four leadership competences that are influential in an effective leader. They are:

a) Management of attention as set of intension, or a vision in a sense of outcome goal or direction.

b) Management by making dreams influential to others and aligning people with dreams through articulate communication skills. It also involves making ideas real to others while supporting their realization.

c) Self management by involving learning and mastery to the point of regarding failure as only mistakes that provide feedback and reveals the next line of action.

d) Trust management vis-a-viz consistency, reliability and focus. 


\subsection{Creativity and Effectiveness in Leadership}

According to Olajide (2003) creativity is the ability to use one's skills, initiative and imagination to produce something new. Fred (2006) described this leadership quality as the capacity to create or catch vision, the desire to detach from the statuesque and create new ideas to ensure the achievement of the set goals of an organization. He submitted that a person who does not feel the thrill of challenge couldn't be an effective leader. Weust and Bucher (2009) stated that creating a vision is the most critical of all leadership skills. Effective leaders create a shared vision and foster a sense of commitment. They align and motivate the group toward the attainment of the vision. A leader that is creative will be able to see where the organization is headed, reposition it, build and promote a strong team in the new direction and motivate his or her team to reach that goal as quickly as possible. According to Horine (2009), a successful administrator should remain fresh and forward thinking, have imagination and be able to innovate. He should create a climate in which ideas germinate and see potential problems before they occur and head them off. The ability to do all these, results in effective leadership. Karen (2009) submitted that there is one sure way to kill a good team: playing team members off each other. He warned against creating internal atmosphere of competition between members because it limits creativity and inhibits progress. According to Wuest and Bucher (2009) creativity is the act of turning new and imaginative ideas into realty. Creativity involves two processes thinking, and then producing. Innovation is the production or implementation of an idea. If you have ideas, but don't act on them, you are imaginative but not creative. A leader that is creative should be able to turn new and imaginative ideas into reality. He should be able to think ahead of the organization and imagine new ideas which when put in place can move the team or organization forward. Any leader that has these qualities is a creative leader and would surely be effective with his group.

In the same vein, Ajidiah, (2001) sees creativity as the process of bringing something new into being. Creativity requires passion and commitment. Out of the creative act is born symbols and myths. It brings to our awareness what was previously hidden and point to new life. A creative leader can bring something out of a new idea and make work out positively in an organization. He must have passion and commitment to do this. Leadership therefore needs transformation in all spheres. A leader should be focus so as to move the organization forward very quickly. The goal is to address major gaps and challenges with solutions that can be developed and applied quickly. It is only in a creative leader that these attributes are seen.

\subsection{Communication Competences in Leadership}

Olajide (2003) pointed out that communication competency is the ability or process of expressing ideas and feelings or of giving people information. Stressing the importance of communication competencies to leadership, Karen (2003) maintain that most people agreed that, the ability to communicate within an organization is of paramount importance. This is because even if administrators possess other leadership qualities, but cannot communicate well, they will never be great. Ogunsaya (2007) Considered high level of information acquisition capacity a factor that leads to effectiveness. Hence, the importance of effective communication and information management in a school organization cannot be overemphasized. Communicating is both a cognitive as well as a behavioral process. Leaders who appear to demonstrate communication competence use their cognitive ability to develop and produce messages which are adapted to the situation, and display those messages through their behavioural skills. Leaders who are emotionally intelligent are also said to be good communicators. The ability to accurately perceive emotion, use emotional messages and manage emotion, assists these leaders in receiving and producing messages to build relationships and promote growth. Hence, an understanding of the relationship between communication competence and emotional intelligence can provide insights into the potential contribution of this important nexus. Karen (2003) further submitted that one of the signs of excellent communication skill is the ability to talk fluently among peers and yet be an equally skilled translator. Good communication according to him is the key to effective leadership. Giving credence to the above, Horine (2009) opined that an effective administrator must have excellent verbal and writing skills. According to him, a tremendous amount of paper work is generated in our public educational systems, which require administrators to spend a great deal of time interpreting or writing materials. Particularly in the area of school management, the administrator uses verbal skills. The leader will chair numerous meetings, appear on radio and television, and speak at student gathering, service clubs, parents groups and faculty meetings.

Akintunde (2001) pointed out that communication involves demonstration and practice of act of listening, speaking, reading, writing and language usage. Communication skills according to Wuest and Bucher (1999) are critical. The ability to speak effectively in public, listen carefully and write with clarity is important. Leaders must be able to convey their communication, their vision and understand the concerns of the group to be effective. However, Warran (2000) view communication from another angle. He submits that effective communication in leadership in three critical areas is the key to winning organizational trust and confidence. The areas are: 
a) Helping employees understand the organization overall operational strategy.

b) Helping employees understand how to contribute to achieving key organizational goals and

c) Sharing information with employees on both how the organization is doing and how an employee's own division is doing.

\subsection{Human Relation Competence in Leadership}

Competence in human relations is very vital to effective leadership. It includes personality and sensitivity of a leader. As Horine (1999) opined, to be competent in human relations means being able to motivate and lead personnel to be fair, consistent, decisive and flexible. It means to be bold when appropriate, but humble and compassionate at other times. It implies to be capable of relating to the custodians, the parents, teachers, older students, and the youngest pupils. It means to be an effective listener so that one will be able to conceptualize skills, see the whole picture, and analyze and solve problems in the midst of confusion. Karen (2003) referred to human relation competencies as ability to rally the troops. He said that being a strong motivator can help build a strong team. According to him, an effective leader should think of himself as a motivator for everyone on the team so that they give their best effort for both themselves and the team. Having the desire to achieve, from a leadership perspective to be able to set a high expectation around a goal requires being able to motivate an organization to achieve those goals and a leader with sound human relations competencies will do these with ease.

Supporting this, Ituh (2005) submitted that human relations in administration refer to that positive attitude of a good personnel administrator. The ability to get along with associates in work is an essential qualification for an administrator because without it there is no co-operation, and without co-operation there is no achievement. Warren (2000) also submitted that an effective leader should know human nature and the importance of sincerely caring for them. A leader who is nonchalant about the feelings of his employees cannot receive their co-operation, and consequently will not be an effective leader. The goals and objectives of an organization according to him are better achieved in a conducive environment where employees are well motivated.

Corroborating this statement, Wuest and Bucher (2009) submitted that leaders must have passion for people, exemplified not by words but by action. They should be concerned about the well being and happiness of their people and be aware of their desire and goals. Doing this in no small measure fosters the effectiveness of a leader. To enhance positive human relations the administrator must affirmatively plan and embrace humanization. The process of humanizing any area involves special attention to basic needs such as recognition, caring, acceptance, self-esteem, identity, security, freedom and power to achieve goal and clear values.

\section{Methodology}

\subsection{Research Method}

Survey research design was used for this study.

\subsection{Population of the Study}

The population of the study was four hundred (400) comprising principals and vice principals of public secondary schools in the State.

\subsection{Sample and Sampling Technique}

The selection of the schools for the study was done by stratified sampling based on education zones. Simple random sampling was used to select schools in each zone. The subject of the study (the principals and vice principals) of the 230 public secondary schools were purposively sampled.

\subsection{Instrumentation}

A questionnaire titled Agricultural Science Teachers Leadership Characteristics and Job performance (ASTLCAJP) was the instrument used for the collection of data for the study.

\subsection{Procedure for Data Collection}

The instrument was administered by the researcher with the help of research assistants.

\subsection{Data Analysis Technique}

Data collected were analyzed using mean, standard deviation and Pearson Product Moment Correlation statistics. 


\section{Results and Discussion of Findings}

The results of data analysis, the findings that emerged from it and the discussion of these findings are presented as per the hypothesis of the study.

\subsection{Hypothesis One}

This hypothesis states that there is no significant relationship between Agricultural Science teachers' creativity and job performance in Akwa Ibom State. The result of the analysis is presented in Table 1.

\section{$<$ Table 1 about here>}

The result presented in Table I showed that the calculated r-values for lesson plan (0.27), instructional material (0.42), knowledge of subject matter (0.27), classroom management (0.24), evaluation (0.51) and professional and personal qualities (0.51) were relatively higher than the critical $r$ value of 0.098 at 0.05 level of significance with 398 degrees of freedom. This indicated that there was a significant relationship between secondary school agricultural science teachers' creativity in leadership and their job performance hence the null hypothesis was rejected.

This finding was in line with Olajide (2003) who asserted that creativity is the ability to use ones skills, initiative and imagination to produce something new. Fred (2006) described this leadership quality as the capacity to create or catch vision, the desire to detach from the statuesque and create new ideas to ensure the achievement of the set goals of an organization. He submitted that a person who does not feel the thrill of challenge couldn't be an effective leader. Weust and Bucher (2009) maintained that creating a vision is the most critical of all leadership skills. Effective leaders create a shared vision and foster a sense of commitment. They align and motivate the group toward the attainment of the vision.

A leader that is creative will be able to see where the organization is headed, reposition it, build and promote a strong team in the new direction and motivate his or her team to reach that goal as quickly as possible (Karen 2003). According to Horine (2009) a successful administrator should remain fresh and forward thinking, have imagination and be able to innovate. He should create a climate in which ideas germinate and see potential problems before they occur and head-them off. The ability to do all these, results in effective leadership.

\subsection{Hypothesis Two}

This hypothesis states that communication competences in leadership do not significantly relate to secondary school agricultural science teachers' job performance.

The result of the analysis is presented in Table 2 .

<Table 2 about here>

The result in Table 2 showed that the calculated r-values for lesson plan (0.31), instructional material (0.42), and knowledge of subject matter (0.27), classroom management (0.23), and evaluation (0.41), and professional/personal qualities (0.49) were higher than the critical r-value of 0.098 at .05 level of significance with 398 degrees of freedom. With this result, the hypothesis was rejected. This implied that there was a significant relationship between communication competences in leadership of secondary school agricultural science teachers and their job performance.

This finding was in agreement with Olajide (2003) who pointed out that communication competency is the ability or process of expressing ideas and feelings or of giving people information. Stressing the importance of communication competencies to effective leadership, Karen (2003) reported that most people who express their view in an opinion poll conducted to ascertain the importance of communication to effective leadership agreed that ability to communicate within an organization decidedly took the first position. This is because even if administrators possess other leadership qualities, but cannot communicate well, they will never be great. Ogunsaya (2007) considered high level of information acquisition capacity as a factor that leads to effectiveness in leadership. Hence the importance of effective communication and information management in an organization cannot be overemphasized.

Karen (2003) further submitted that one of the signs of excellent communication skill is the ability to talk fluently among peers and yet be an equally skilled translator. Good communication according to him is the key to an effective leadership. Giving credence to the above, Horine (1999) opined that an effective administrator must have excellent verbal and writing skills. According to him, a tremendous amount of paper work is generated in our public educational systems which require administrators to spend a great deal of time interpreting or writing materials. Particularly in the area of agricultural communication, the administrator uses verbal skills. The leader will chair numerous meetings, appear on radio and television, and speak at student gatherings, service clubs, parents groups and faculty meetings. The ability to speak effectively in public, listen carefully and write with clarity is important. Leaders must be able to convey and communicate their vision and understand the concerns of the group to be effective. 


\subsection{Hypothesis Three}

This hypothesis states that human relation competences in leadership of secondary school agricultural science teachers does not significantly relate to their job performance.

The result of the analysis is presented in Table 3

\section{$<$ Table 3 about here>}

The result of the analysis presented in Table 3 revealed that each of the calculated r-values for lesson plan (0.35), instructional materials (0.40), knowledge of subject matter (0.28), classroom management (0.24), evaluation (0.53), and professional/personal qualities (0.41) were higher than the critical r-value of .098 at .05 level of significance with 398 degrees of freedom. With this result, the null hypothesis was rejected. This result therefore indicated that human relation competences in leadership of secondary school agricultural science teachers had a significant relationship with their job performance.

The finding was supported by Olajide (2003) who pointed out that competence in human relation is very vital to effective leadership. It includes personality and sensitivity of a leader. As Horine (1999) opined, to be competent in human relations means being able to motivate and lead personnel, to be fair, consistent, decisive and flexible. It means to be bold when appropriate, but humble and compassionate at other times. It implies being capable of relating to the custodians, the parents, teachers, older students, and the youngest pupils. It means to be an effective listener, to be able to conceptualize skills, see the whole picture and analyze and solve problems in the midst of confusion. Karen (2003) referred to human relation competencies as ability to rally the troops. He said that being a strong motivator can help build a strong team. According to him, an effective leader should think of himself as a motivator for everyone on the team so that they give their best effort for both themselves and the team. Having the desire to achieve from a leadership perspective means to be able to set a high expectation around a goal. This requires being able to motivate an organization to achieve those goals and a leader with sound human relations competencies will do with ease.

The ability to get along with associates in work is an essential qualification for an administrator because without it there is no cooperation, and without co-operation there is no achievement. Warren (2000) also submitted that an effective leader should know human nature and the importance of sincerely caring for them. A leader who is nonchalant about the feelings of his employees cannot receive their cooperation and consequently will not be an effective leader. The goals and objectives of an organization according to him are better achieved in conducive environment where employees are well motivated.

Corroborating this, Wuest and Bucher (2009) submitted that leaders must have passion for people exemplified not by words but by action. They should be concerned about the well-being and happiness of their people and be aware of their desire and goals. Doing these amounts to good human relations and in no small measure fosters the effectiveness of a leader. To enhance positive human relations agricultural Science teachers must affirmatively plan and embrace humanization. The process of humanizing any area involves paying special attention to basic needs such as recognition, caring, acceptance, self-esteem, identity, security, freedom and power to achieve goals and clear values.

\section{Conclusion}

Based on the results of the study, it was concluded that creativity in leadership; communication competences in leadership; and human relation competences in leadership of secondary school agricultural science teachers significantly relate to their job performance in Akwa Ibom State.

\section{Recommendations}

Based on the results and findings of the study the following recommendations were made:

1) Secondary school agricultural science teachers should be encouraged to be more creative to enhance their job performance.

2) Agricultural Science teachers should adopt different communication strategies such as speaking effectively in public, listening carefully and writing with clarity so as to enhance effective performance on the job.

3) They should adopt good human relationship that would influence agricultural activities in the State 


\section{References}

Adair, J. (2002) Effective Strategic Leadership, in V. Koteinikove (Ed). Effective Leadership. Australia: Tec Republic.

Ajidiah, A. O. (2001). Revitalizing Agricultural Education in Nigeria: Practices, Problems and Prospects. Reports of National Committee on Problems on Agricultural Development in Nigeria, 3, 37 - 57.

Akwa Ibom State Ministry of Education (2001). Performance of students in the state and national examinations. Uyo: Government House Press

Akintunde, P. G. (2001) Administration and Organization of Agricultural Education Programmes in Nigeria. Ibadan: Yew Printers.

Ayodabo, O. (2004). The Relationship Between Leadership Styles and the Achievement of Agricultural Education Administrators of Selected Universities in Nigeria. Unpublished Ph.D thesis: University of Nigeria, Nsukka.

Babajide, E. O. (2000). A Comparative Analysis of Leadership Styles of Males and Females Management in Banking Industries in Southwestern Nigeria. Unpublished Ph.D thesis, University of Ibadan, Nigeria

Bennis, W. (2008) Learning about Leadership .USA University System News. 5, (2), 5, 9 \& 10.

Fred, S. (1996). Leadership Journal 17, (4), 2 - 3.

Horine, L. (2009) Administration of Agricultural Education Programme USA: McGraw Hill.

Ikhioya, O. S. A. (2001). Functional Strategies for Effective Administrators: Lagos: Agriculture Consults.

Ituh, M. C. (2005). The Physiology/Pharmacology of Drugs and teaching Performance. Journal of Nigeria Academy of Education 3 (1), 7 - 11.

Karen, A. R. (2003). Top Ten Leadership Qualities of Successful Teachers of Agriculture. Australia: Tec Republic, ING.

McNamara, C. (2009) Overview of Leadership in Organization: Nut-and-Bolts Guide to Leadership and Supervision. New York: Harper and Row Publishers.

Ogunsanya, M. (2007) Fiscal Factors as a Determinant of Worker Performance. African Journal of Educational Management $\underline{5}(1 \& 2), 187$.

Olajide, O. A. (2003) Vandalism: Limiting Factors in Organization and Administration of Agricultural programmes. Unpublished M. Ed. Thesis, University of Nigeria, Nsukka.

Richard, F. (2004) Management Strategies in Agricultural Training. USA: Hud Publishers

Vannier, M. \& Gallahue, D. L. (2008). The Teaching of Agriculture in Elementary Schools. Philadelpha: London W. B. Saunder Company.

Warren, B. (2000) Becoming a Leader. http://www. Nwlink.com/dondark/leader/lead.com.html retrieved. Retrieved 23/8/2011

Wuest, D. A. \& Burcher, C. A. \& Burcher, C. A. (2009) Foundations of Agricultural Education . New York: McGraw-Hill Company. 
Table 1. Pearson Product Moment Correlation analysis of the relationship between Agricultural science teachers' creativity in leadership and job performance $(\mathrm{N}=400)$

\begin{tabular}{|l|c|l|l|}
\hline \multicolumn{1}{|c|}{ Variables } & $\bar{x}$ & $\mathrm{SD}$ & r-value \\
\hline Creativity Plan & $\mathrm{X} 30.32$ & 1.90 & \\
\hline Lesson Plan & $\mathrm{Y}_{1} 29.98$ & 1.56 & 0.27 \\
\hline Instructional Materials & $\mathrm{Y}_{2} 30.24$ & 1.62 & 0.42 \\
\hline Knowledge of Subject matter & $\mathrm{Y}_{3} 31.10$ & 1.32 & 0.27 \\
\hline Classroom Management & $\mathrm{Y}_{4} 30.46$ & 1.30 & 0.24 \\
\hline Evaluation & $\mathrm{Y}_{5} 30.32$ & 1.62 & 0.51 \\
\hline Professional/Personal qualities & $\mathrm{Y}_{6} 30.36$ & 1.09 & 0.51 \\
\hline
\end{tabular}

Table 2. Pearson Product Moment Correlation analysis of the relationship between communication competence and agricultural science teachers' job performance $(\mathrm{N}=400)$.

\begin{tabular}{|l|c|l|l|}
\hline \multicolumn{1}{|c|}{ Variables } & $\bar{x}$ & $\mathrm{SD}$ & $\mathrm{r}$-value \\
\hline Communication Competences & $\mathrm{X}^{2} 31.28$ & 2.12 & \\
\hline Lesson Plan & $\mathrm{Y}_{1} 29.98$ & 1.56 & 0.31 \\
\hline Instructional Materials & $\mathrm{Y}_{2} 30.24$ & 1.62 & 0.42 \\
\hline Knowledge of Subject matter & $\mathrm{Y}_{3} 31.1 \mathrm{O}$ & 1.32 & 0.27 \\
\hline Classroom Management & $\mathrm{Y}_{4} 30.46$ & 1.30 & 0.23 \\
\hline Evaluation & $\mathrm{Y}_{5} 30.32$ & 1.62 & 0.41 \\
\hline Professional/Personal qualities & $\mathrm{Y}_{6} 30.36$ & 1.09 & 0.49 \\
\hline
\end{tabular}

$\mathrm{N}=400 ;$ significant at 0.05 ; Critical $\mathrm{r}=0.098 ; \mathrm{df}=398$

Table 3. Pearson Product Moment Correlation analysis of the relation between agricultural science teachers' human relation competences and their job performance $(\mathrm{N}=400)$.

\begin{tabular}{|l|c|c|c|}
\hline \multicolumn{1}{|c|}{ Variables } & $\bar{x}$ & $\mathrm{SD}$ & r-values \\
\hline Human relation Competence & $\mathrm{X} 30.26$ & 1.47 & \\
\hline Lesson Plan & $\mathrm{Y}_{1} 29.98$ & 1.56 & 0.35 \\
\hline Instructional Materials & $\mathrm{Y}_{2} 3 \mathrm{O} .24$ & 1.62 & 0.40 \\
\hline Knowledge of Subject matter & $\mathrm{Y}_{3} 31.10$ & 1.32 & 0.28 \\
\hline Classroom Management & $\mathrm{Y}_{4} 30.46$ & 1.30 & 0.24 \\
\hline Evaluation & $\mathrm{Y}_{5} 30.32$ & 1.62 & 0.53 \\
\hline Professional/Personal Qualities & $\mathrm{Y}_{6} 30.36$ & 1.09 & 0.41 \\
\hline
\end{tabular}

$\mathrm{N}=400 ;$ significant at 0.05; Critical $\mathrm{r}=0.098 ; \mathrm{df}=398$ 